AKUNTABILITAS

Vol. VIII No. 2, Agustus 2015

P-ISSN: $1979-858 \mathrm{X}$

Halaman $148-161$

\title{
PENGARUH KEJELASAN SASARAN ANGGARAN, STRUKTUR DESENTRALISASI DAN LOCUS OF CONTROL TERHADAP KINERJA MANAJERIAL
}

\author{
Taufik Hidayat \\ UIN Syarif Hidayatullah Jakarta
}

\begin{abstract}
The objective of this research is to know the empirical influence of budget goal clarity, structure of decentralization, and Locus of control toward managerial performance. The data were collected by survey method are using questionaire as primer data agregation. The sample of this research are 65 leader and staff in state islamic university sharif hidayatullah Jakarta. Field research are using purposive sampling method. Data has been analyze use validity test, reliability test, multiple linear regression, classical assumption test, t-test, F-test and determination coefficient. The result of this research are budget goal clarity influence significantly to managerial performance structure of decentralization influence significantly to managerial performance and Locus of control not influence to managerial performance
\end{abstract}

Keywords: budget goal clarity, structure of decentralization, Locus of control, job managerial performance.

ABSTRAK: Tujuan dari penelitian ini adalah untuk mengetahui bukti empiris mengenai pengaruh kejelasan sasaran anggaran, struktur desentralisasi, dan Locus of control terhadap kinerja manajerial. Data dikumpulkan dengan metode survei menggunakan kuesioner sebagai data primer. Sampel penelitian ini adalah 65 pemimpin dan staf di Universitas Islam Negeri Syarif Hidayatullah Jakarta. Penelitian lapangan menggunakan metode purposive sampling. Data analisis menggunakan uji validitas, uji reliabilitas, regresi linier berganda, uji asumsi klasik, uji t, uji F dan koefisien determinasi. Hasil penelitian ini adalah sasaran anggaran kejelasan berpengaruh signifikan terhadap kinerja manajerial, struktur desentralisasi berpengaruh secara signifikan terhadap kinerja manajerial dan Locus of control tidak berpengaruh terhadap kinerja manajerial

Kata kunci: anggaran kejelasan sasaran, struktur desentralisasi, Locus of control, kinerja manajerial pekerjaan.

\footnotetext{
${ }^{1}$ Draft pertama: 15 April 2015 ; Revisi: 16 Mei 2015 ; Diterima: 15 Juli 2015

Penulis dapat dikontak melalui: taufik.hidayat@uinjkt.ac.id
} 


\section{PENDAHULUAN}

Kinerja manajerial menunjukkan kemampuan dan prestasi seorang manajer dalam menjalankan organisasi untuk mewujudkan tujuan yang mengarah kepada ketercapaian pelayanan publik. Kepentingan kinerja manajerial dibutuhkan untuk menilai seberapa jauh lembaga/organisasi dapat menerapkan visi, misinya agar pelayanan publik dapat terwujud. Salah satu bentuk konsistensinya adalah perlu dilakukannya bentuk aktivitas yaitu melakukan penjaringan aspirasi masyarakat dan adanya kejelasan dalam partisipasi penyusunan anggaran yang terpadu sehingga dapat tercapai suatu sistem yang dapat mencegah atau meminimalisasi terjadinya kesalahan dalam mewujudkan good governance.

Kinerja manajer akan dikatakan efektif apabila tujuan organisasi yang telah tertuang dalam anggaran dapat dicapai. Kejelasan sasaran anggaran mencerminkan sejauh mana tujuan anggaran ditetapkan secara spesifik dan jelas sehingga dapat dipahami oleh orang yang bertanggung jawab dalam pencapaiannya. Apabila sasaran tidak disebutkan secara spesifik akan menyebabkan kebingungan yang akan berdampak buruk terhadap kinerja.

Diperkirakan tidak satupun akademisi maupun praktisi di bidang bisnis termasuk akuntasi yang menolak pernyataan bahwa tingkat atau intensitas partisipasi anggaran dan derajat struktur organisasi yang terdesentralisasi akan meningkatkan atau menurunkan kinerja orang yang terlibat dalam partisipasi dan struktur tersebut.

Di samping komitmen organisasi yang dimiliki, kebutuhan informasi manajerial dalam menyusun anggaran juga dipengaruhi faktor personalitas (personality factor) yang ditunjukkan dengan locus of control. Menurut Astuti (2007) locus of control adalah sikap seseorang dalam mengartikan sebab dari suatu pristiwa, artinya locus of control harus dijadikan sebagai pertimbangan dalam menentukan kebutuhan informasi seorang manajer untuk memprediksi ketidakpastian lingkungan dalam penyusunan anggaran.

Struktur organisasi desentralisasi secara umum ditujukan dengan pengambilan keputusan yang terjadi dalam organisasi. Dalam struktur sentralisasi yang tinggi, sebagian keputusan diambil pada tingkat hirarki organisasi yang tertinggi, dan apabila sebagian otorisasi didelegasikan pada level yang rendah dalam organisasi, maka organisasi tersebut lebih desentralisasi.

Penyusunan anggaran pada tingkat satuan kerja juga akan melibatkan bagianbagian/sub bagian yang ada dalam satuan kerja tersebut, karena bagian-bagian/sub bagian inilah yang akan melaksanakan semua program kerja dan anggaran yang akan disusun. Oleh karena itu keterlibatan/partisipasi aktif dari masing-masing kepala bagian/sub bagian sangat diperlukan supaya anggaran yang disusun mampu mengakomodir kebutuhankebutuhan masing-masing bagian/sub bagian tersebut. Dalam implementasinya pada tahapan inilah selalu terjadi keterlambatan dalam pengusulan program dan kegiatannya, akibatnya pimpinan tertinggi dari satuan kerja tersebut menyusun anggaran untuk tahun yang akan datang dengan dasar realisasi anggaran tahun yang lalu ditambah dengan estimasi kenaikan-kenaikan yang dianggap wajar.

Keterlambatan dalam pengusulan program kegiatan oleh masing-masing bagian dalam satuan kerja akan memberikan dampak terhadap kinerja satuan kerja dalam memberikan pelayanan kepada publik. Menurut Suryadi dalam Suprantiningrum (2003) kinerja merupakan hasil kerja yang dapat dicapai oleh seorang atau kelompok orang dalam suatu organisasi, sesuai dengan wewenang dan tanggung jawab masing-masing, dalam rangka upaya pencapaian tujuan organisasi bersangkutan secara legal, tidak melanggar hukum dan sesuai dengan moral maupun etika. 
Tujuan dalam penelitian ini adalah untuk memberikan bukti empiris mengenai pengaruh kejelasan sasaran anggaran, struktur desentralisasi, locus of control terhadap kinerja manajerial.

\section{KERANGKA TEORI DAN PENGEMBANGAN HIPOTESIS}

\section{Kinerja Manajerial}

Kinerja merupakan suatu prestasi atau tingkat keberhasilan yang dicapai oleh individu atau suatu organisasi dalam melaksanakan pada suatu periode tertentu. Menurut Stoner (1986) kinerja (performance) merupakan kuantitas dan kualitas pekerjaan yang diselesaikan oleh individu, kelompok atau organisasi. Pada sector pemerintahan, kinerja dapat diartikan sebagai suatu prestasi yang dicapai oleh pegawai pemerintah atau instansi pemerintah dalam melaksanakan pelayanan kepada masyarakat dalam suatu periode.

Kinerja manajerial merupakan kinerja para individu dalam kegiatan-kegiatan manajerial, seperti: perencanaan, investigasi, koordinasi, evaluasi, pengawasan, pengaturan staf, negosiasi dan perwakilan (Mahoney, 1963). Kinerja sebagai hasil kerja yang dapat dicapai oleh seseorang atau sekolompok orang dalam suatu organisasi sesuai dengan wewenang dan tanggung jawab masing-masing dalam upaya mencapai tujuan organisasi yang bersangkutan secara legal, tidak melanggar hukum dan sesuai dengan moral dan etika (Prawirosentono, 1999). Kinerja merupakan faktor penting yang digunakan untuk mengukur efektitas dan efisiensi organisasi. Menurut Supomo dan Indriantoro (1998) bahwa: "Kinerja manajerial adalah kinerja para individu anggota organisasi dalam kegiatankegiatan manajerial, antara lain: perencanaan, koordinasi, supervisi, staffing, negosiasi, dan representasi”. Bagi organisasi itu sendiri kinerja manajerial dapat menjadi tolak ukur sejauh mana manajer melaksakanan fungsi manajemen. Mahoney (1963) mengukur kinerja manajerial dengan indikator:

1. Perencanaan, yaitu tindakan yang dibuat berdasarkan fakta dan asumsi yang akan datang guna mencapai tujuan yang diinginkan.

2. Investigasi, yaitu upaya yang dilakukan untuk mengumpulkan dan mempersiapkan informasi dalam bentuk laporan-laporan. Catatan dan analisa pekerjaan untuk dapat mengukur hasil pelaksanaannya.

3. Koodinasi, menyelaraskan tindakan yang meliputi pertukaran informasi dengan orangorang dalam unit organisasi lainnya, guna dapat berhubungan dan menyesuaikan program yang akan dijalankan.

4. Evaluasi, yaitu penilaian atas usulan atau kinerja yang diamati dan dilaporkan.

5. Supervisi, yaitu mengarahkan, memimpin dan mengembangkan potensi bawahan serta melatih dan menjelaskan aturan-aturan kerja kepada bawahan.

6. Staffing, yaitu memelihara dan mempertahankan bawahan dalam suatu unit kerja, menyeleksi pekerjaan baru menempatkan dan mempromosikan pekerjaan tersebut dalam unit lainnya.

7. Negosiasi, yaitu usaha untuk memperoleh kesepakatan dalam hal pembelian, penjualan atau kontrak untuk barang-barang dan jasa.

8. Representasi, yaitu menyampaikan informasi tentang visi, misi dan kegiatan-kegiatan organisasi dengan menghadiri pertemuan kelompok bisnis dan konsultasi dengan perusahaan-perusahaan lainnya.

Penilaian kinerja adalah penentuan secara periodik efektifitas operasional suatu organisasi, bagian organisasi dan personelnya, berdasarkan sasaran, standar dan criteria yang ditetapkan sebelumnya. Perlu diingat bahwa penilaian kinerja adalah untuk memotivasi personel dalam mencapai tujuan organisasi. Dalam organisasi pemerintah, pengukuran kinerja pimpinan dilakukan untuk menilai seberapa baik pimpinan tersebut 
melakukan tugas pokok dan fungsi yang dilimpahkan kepadanya selama periode tertentu. Pengukuran kinerja pimpinan merupakan wujud dari pertanggungjawaban baik secara vertical accountability yaitu pengevaluasian kinerja bawahan oleh atasan dan sebagai bahan pertanggungjawaban secara horizontal pemerintah kepada masyarakat atas amanah yang diberikan kepadanya.

Wayne C. Parker (1993:3) dalam Sadjiarto Arja (2000) menyebutkan lima manfaat adanya pengukuran/penilaian kinerja suatu entitas pemerintahan yaitu:

1. Peningkatan kinerja meningkatkan mutu pengambilan keputusan.

Seringkali keputusan yang diambil pemerintah dilakukan dalam keterbatasan data dan berbagai pertimbangan politik serta tekanan dari pihak-pihak yang berkepentingan. Proses pengembangan pengukuran kinerja ini akan memungkinkan pemerintah untuk menentukan misi dan menetapkan tujuan pencapaian hasil tertentu. Di samping itu dapat juga dipilih metode pengukuran kinerja untuk melihat kesuksesan program yang ada. Di sisi lain, adanya pengukuran kinerja membuat pihak legislatif dapat memfokuskan perhatian pada hasil yang didapat, memberikan evaluasi yang benar tehadap pelaksanaan anggaran serta melakukan diskusi mengenai usulan-usulan program baru.

2. Pengukuran kinerja meningkatkan akuntabilitas internal.

Dengan adanya pengukuran kinerja ini, secara otomatis akan tercipta akuntabilitas di seluruh lini pemerintahan, dari lini terbawah sampai teratas. Lini teratas pun kemudian akan bertanggungjawab kepada pihak legislatif. Dalam hal ini disarankan pemakaian sistem pengukuran standar seperti halnya management by objectives untuk pengukuran outputs dan outcomes.

3. Pengukuran kinerja meningkatkan akuntabilitas publik.

Meskipun bagi sebagian pihak, pelaporan evaluasi kinerja pemerintah kepada masyarakat dirasakan cukup menakutkan, namun publikasi laporan ini sangat penting dalam keberhasilan sistem pengukuran kinerja yang baik. Keterlibatan masyarakat terhadap pengambilan kebijakan pemerintah menjadi semakin besar dan kualitas hasil suatu program juga semakin diperhatikan.

4. Pengukuran kinerja mendukung perencanaan strategi dan penetapan tujuan.

Proses perencanaan strategi dan tujuan akan kurang berarti tanpa adanya kemampuan untuk mengukur kinerja dan kemajuan suatu program. Tanpa ukuranukuran ini, kesuksesan suatu program juga tidak pernah akan dinilai dengan obyektif.

5. Pengukuran kinerja memungkinkan suatu entitas untuk menentukan penggunaan sumber daya secara efektif.

Masyarakat semakin kritis untuk menilai program-program pokok pemerintah sehubungan dengan meningkatnya pajak yang dikenakan kepada mereka. Evaluasi yang dilakukan cenderung mengarah kepada penilaian apakah pemerintah memang dapat memberikan pelayanan yang terbaik kepada masyarakat. Dalam hal ini pemerintah juga mempunyai kesempatan untuk menyerahkan sebagian pelayanan publik kepada sektor swasta dengan tetap bertujuan untuk memberikan pelayanan yang terbaik.

\section{Kejelasan Sasaran Anggaran}

Menurut Kenis (1979), kejelasan sasaran anggaran merupakan sejauhmana tujuan anggaran ditetapkan secara jelas dan spesifik dengan tujuan agar anggaran tersebut dapat dimengerti oleh orang yang bertanggung jawab atas pencapaian sasaran anggaran tersebut. Oleh sebab itu sasaran anggaran pemerintah daerah harus dinyatakan secara jelas, spesifik dan dapat dimengerti oleh mereka yang bertanggung jawab untuk melaksanakannya. Locke (1968) dalam Kenis (1979) menyatakan bahwa penetapan tujuan spesifik akan lebih produktif. Hal ini akan mendorong karyawan/ Staf untuk melakukan yang terbaik bagi 
pencapaian tujuan yang dikehendaki sehingga berimplikasi pada peningkatan kinerja. Beberapa penelitian seperti Lathan dan Yuki (1975), Streers (1976), Ivancevich (1976) dalam kenis (1979), Darma (2004) menunjukkan adanya pengaruh positif antara kejelasan sasaran anggaran dan sasaran anggaran yang spesifik dengan kinerja manajerial. Locke (1968) dalam Kenis (1979) menyatakan kejelasan sasaran anggaran disengaja untuk mengatur perilaku pegawai.

Ketidakjelasan sasaran anggaran akan menyebabkan pelaksanaan anggaran menjadi bingung, dan tidak puas dalam bekerja. Hal ini menyebabkan pelaksana anggaran tidak termotivasi untuk mencapai kinerja yang diharapkan. Kenis (1979) menemukan bahwa pelaksana anggaran memberikan realisasi positif dan secara relatif sangat kuat untuk meningkatkan kejelasan sasaran anggaran. Reaksi tersebut adalah peningkatan kepuasan kerja, penurunan ketegangan kerja, peningkatan sikap pegawai terhadap anggaran, kinerja anggaran dan efisiensi biaya pada pelaksana anggaran secara signifikan jika sasaran anggaran dinyatakan secara jelas. Kenis juga menyatakan bahwa anggaran tidak hanya sebagai alat perencanaan dan pengendalian biaya dan pendapatan dalam pusat pertanggungjawaban dalam suatu organisasi, sisi lain anggaran juga merupakan alat bagi manajerial Satua Kerja untuk mengkoordinasikan, mengkomunikasikan, mengevaluasi kinerja dan memotivasi bawahannya.

Riyanto (2003) menyatakan hubungan karakteristik anggaran, dalam hal ini kejelasan sasaran anggaran, dengan kinerja dipengaruhi oleh faktor-faktor individual yang bersifat psychological atribute. Efektif atau tidaknya kejelasan sasaran anggaran sangat ditentukan oleh psycological atribute, sehingga faktor-faktor individual tersebut sangat dipengaruhi oleh kejelasan sasaran anggaran dalam menilai kinerja manajerial Satuan Kerja.

Kejelasan sasaran anggaran akan membantu pegawai untuk mencapai kinerja yang diharapkan, dimana dengan mengetahui sasaran anggaran tingkat kinerja dapat tercapai. Pencapaian kinerja ini akan terkait dengan motivasi, dimana hal ini disebabkan dengan motivasi yang tinggi akan membantu pegawai untuk mencapai kinerja yang diharapkan. Dengan kata lain, kinerja menejerial akan dipengaruhi oleh kejelasan sasaran anggaran.

H1: Kejelasan sasaran anggaran berpengaruh terhadap kinerja manajerial

\section{Struktur Desentralisasi}

Diperkirakan tidak satupun akademisi maupun praktisi di bidang bisnis termasuk akuntasi yang menolak pernyataan bahwa tingkat atau intensitas partisipasi anggaran dan derajat struktur organisasi yang terdesentralisasi akan meningkatkan atau menurunkan kinerja orang yang terlibat dalam partisipasi dan struktur tersebut.

Struktur organisasi desentralisasi secara umum ditujukan dengan pengambilan keputusan yang terjadi dalam organisasi. Dalam struktur sentralisasi yang tinggi, sebagian keputusan diambil pada tingkat hirarki organisasi yang tertinggi, dan apabila sebagian otorisasi didelegasikan pada level yang rendah dalam organisasi, maka organisasi tersebut lebih desentralisasi.

Adapun definisi desentralisasi menurut Simon (1989) yaitu suatu organisasi administratif adalah sentralisasi yang luas apabila keputusan yang dibuat pada level organisasi yang tinggi, desentralisasi yang luas apabila keputusan didelegasikan dari top menejemen kepada level yang rendah dari wewenang eksekutif.

Dengan demikian desentraslisai akan membuat tanggung jawab yang lebih besar kepada manajerial dalam melaksanakan tugasnya, serta memberikan kebebasan dalam bertindak. Dengan desentralisasi akan meningkatkan independensi manajerial dalam berfikir dan bertindak dalam satu tim tanpa mengorbankan kebutuhan organisasi. Desentralisasi membutuhkan keseimbangan manajerial yang independen dengan timnya dan komitmennya pada organisasi. Siegel dan Marconi (1989) mengemukakan beberapa alasan suatu organisasi membentuk struktur desentralisasi yaitu: 
1. Akan memberikan Top menejemen waktu yang lebih banyak pada keputusan stratejik jangka panjang dari keputusan operasi

2. Dapat membuat organisasi memberikan respon yang lebih cepat dan efektif pada suatu masalah

3. Sistem ini tidak memungkinkan untuk mendapatkan seluruh kebutuhan yang optimal

4. Akan menghasilkan dasar Training yang baik untuk calon Top manajer dimasa yang akan datang

5. Memenuhi kebutuhan otonomi dan kemudian menjadi alat motivasi yang kuat bagi Manajerial

Desentralisasi akan menunjukkan tingkat otonomi yang didelegasikan pada manajerial sehingga manajerial mempunyai tanggung jawab yang lebih besar terhadap perencanaan dan pengendalian aktivitas operasi serta membutuhkan informasi yang lebih banyak. Jadi organisasi yang strukturnya lebih terdesentralisasi seperti pelaksanaan otonomi daerah di Indonesia, para manajerial mempunyai otonomi yang lebih besar dalam proses pengambilan atau penetapan keputusan.

Desentralisasi menurut Pasal 1 ayat (7) UU Nomor 32 Tahun 2004, diartikan sebagai penyerahan wewenang pemerintahan oleh pemerintah kepada daerah otonom untuk mengatur dan mengurus urusan pemerintahan dalam sistem Negara Kesatuan Republik Indonesia. Desentralisasi merupakan penyerahan wewenang dari tingkat pemerintahan yang lebih tinggi kepada pemerintahan yang lebih rendah, baik yang menyangkut bidang legislatif, judikatif, atau administrative. Menurut Hoogerwerf (1978), Desentralisasi adalah pengakuan atau penyerahan wewenang oleh badan-badan umum yang lebih rendah untuk secara mandiri dan berdasarkan pertimbangan kepentingan sendiri mengambil keputusan pengaturan pemerintahan, serta struktur wewenang yang terjadi dari hal itu. Dijabarkan juga oleh Koswara (1996) bahwa Desentralisasi pada dasarnya mempunyai makna yaitu melalui proses desentralisasi urusan-urusan pemerintahan yang semula termasuk wewenang dan tanggung jawab pemerintah pusat sebagian diserahkan kepada pemerintah daerah agar menjadi urusan rumah tangganya sehingga urusan tersebut beralih kepada dan menjadi wewenang dan tanggung jawab pemerintah daerah. Maddick (1963) mengemukakan bahwa desentralisasi adalah suatu cara untuk meningkatkan kemampuan aparat pemerintah dan memperoleh informasi yang lebih baik mengenai keadaan daerah, untuk menyusun program-program daerah secara lebih responsif dan untuk mengantisipasi secara cepat manakala persoalan-persoalan timbul dalam pelaksanaan. Lebih lanjut Soejito (1990) menjelaskan bahwa desentralisasi sebagai suatu sistem dipakai dalam bidang pemerintahan merupakan kebalikan dari sentralisasi, dimana sebagian kewenangan pemerintah pusat dilimpahkan kepada pihak lain untuk dilaksanakan.

H2: Struktur desentralisasi anggaran berpengaruh terhadap kinerja manajerial

\section{Locus Of Control}

Konsep tentang locus of control (pusat kendali) pertama kali dikemukakan oleh Rotter pada tahun 1966 yang merupakan ahli teori pembelajaran sosial. Locus of control dapat diartikan sebagai cara pandang seseorang terhadap suatu peristiwa apakah dia dapat atau tidak dapat mengendalikan (control) peristiwa yang terjadi padanya. Locus of control menurut Hjele dan Ziegler, Baron dan Byren, dalam Astuti (2007) diartikan sebagai perepsi seseorang tentang sebab-sebab keberhasilan atau kegagalan dalam melaksanakan pekerjaannya.

Locus of control merupakan salah satu variabel kepribadian (personility), yang didefenisikan sebagai keyakinan individu terhadap mampu tidaknya mengontrol nasib (destiny) sendiri (Rotter,1966). Lefcourt (1982) menyatakan bahwa Locus of control dibedakan menjadi locus of control internal yaitu yang ditunjukkan dengan pandangan 
bahwa pristiwa baik buruk yang terjadi diakibatkan oleh tindakan seseorang. Oleh karena itu terjadinya suatu pristiwa berada dlam control seserorang. Sedang locus of control external yaitu ditunjukkan dengan pandangan bahwa pristiwa baik buruk yang terjadi tidak berhubungan dengan prilaku seseorang pada situasi tertentu, oleh karena itu disebut dengan diluar control seseorang. Setiap orang memiliki locus of control tertentu yang berada diantara kedua ekstrem tersebut.

Perbedaan karekteristik antara internal locus of control dengan external locus of control menurut Crider (1983) sebagai berikut:

\section{Internal Locus Of Control}

a. Suka bekerja keras

b. Memiliki inisiatif yang tinggi

c. Selalu berusaha untuk menemukan pemecahan masalah

d. Selalu mencoba untuk berfikir seefektif mungkin

e. Selalu mempunyai persepsi bahwa usaha harus dilakukan jika ingin berhasil

\section{External Locus Of Control}

a. Kurang memiliki inisiatif

b. Mempunyai harapan bahwa ada sedikit korelasi antara usaha dan kesuksesan.

c. Kurang suks berusaha, karena mereka percaya bahwa faktor luarlah yang mengontrol

d. Kurang mencari informasi untuk memecahkan masalah

Pada orang-orang yang memiliki internal locus of control faktor kemampuan dan usaha terlihat dominan, oleh karena itu apabila individu dengan internal locus of control mengalami kegagalan akan menyalahkan dirinya sendiri karena kurangnya usaha yang dilakukan. Begitu pula dengan keberhasilan, mereka akan merasa bangga atas hasil usahanya. Sebaliknya orang yang memiliki external locus of control melihat keberhasilan dan kegagalan dari faktor kesukaran dan nasib, oleh karena itu apabila mengalami kegagalan mereka cendrung menyalahkan lingkungan sekitar yang menjadi penyebabnya. Hal ini tentunya berpengaruh terhadap tindakan dimasa datang, karena merasa tidak mampu dan kurang usahanya maka mereka tidak mempunyai harapan untuk memperbaiki kegagalan tersebut. Brownell (1982) mengelompokkan berbagai kondisi Locus of Control kedalam empat kelompok variabel yaitu kultural, organisasional, interpersonal dan individual. Secara individual Locus of control merupakan salah satu faktor mempengaruhi cara pandang seeorang terhadap suatu peristiwa untuk bisa atau tidaknya ia mengendalikan peristiwa tersebut. Kondisi ini memberikan arti bahwa dalam rangkaian penyusunan anggaran tidak terlepas dari peran individu dalam mewujudkan apakah keberhasilan yang dicapai atau kegagalan yang akan terjadi. Hal ini kembali kepada personality seseorang mana yang lebih dominan apakah locus of control intenal atau locus of control external. Semuanya itu akan berpengaruh kepada prilaku pemimpin yang dihubungkan dengan kinerja manajerial.

Locus of Control atau lokus pengendalian yang merupakan kendali individu atas pekerjaan mereka dan kepercayaan mereka terhadap keberhasilan diri. Lokus pengendalian ini terbagi menjadi dua yaitu lokus pengendalian internal yang mencirikan seseorang memiliki keyakinan bahwa mereka bertanggung jawab atas perilaku kerja mereka di organisasi. Lokus pengendalian eksternal yang mencirikan individu yang mempercayai bahwa perilaku kerja dan keberhasilan tugas mereka lebih dikarenakan faktor di luar diri yaitu organisasi.

Konsep tentang Locus of control (pusat kendali) pertama kali dikemukakan oleh Rotter (1966), seorang ahli teori pembelajaran sosial. Locus of control merupakan salah satu variabel kepribadian (personility), yang didefinisikan sebagai keyakinan individu terhadap mampu tidaknya mengontrol nasib (destiny) sendiri (Kreitner dan Kinicki, 2005). 
Robbins dan Judge (2007) mendefinisikan lokus kendali sebagai tingkat dimana individu yakin bahwa mereka adalah penentu nasib mereka sendiri. Internal adalah individu yang yakin bahwa mereka merupakan pemegang kendali atas apa-apa pun yang terjadi pada diri mereka, sedangkan eksternal adalah individu yang yakin bahwa apapun yang terjadi pada diri mereka dikendalikan oleh kekuatan luar seperti keberuntungan dan kesempatan.

Berdasarkan penjelasan di atas dapat disimpulkan bahwa Individu yang memiliki keyakinan bahwa nasib atau event-event dalam kehidupannya berada dibawah kontrol dirinya, dikatakan individu tersebut memiliki internal locus of control. Sementara individu yang memiliki keyakinan bahwa lingkunganlah yang mempunyai kontrol terhadap nasib atau event-event yang terjadi dalam kehidupannya dikatakan individu tersebut memiliki external locus of control.

Kreitner \& Kinichi (2005) mengatakan bahwa hasil yang dicapai locus of control internal dianggap berasal dari aktifitas dirinya. Sedangkan pada individu locus of control eksternal menganggap bahwa keberhasilan yang dicapai dikontrol dari keadaan sekitarnya.

Seseorang yang mempunyai internal locus of control akan memandang dunia sebagai sesuatu yang dapat diramalkan, dan perilaku individu turut berperan di dalamnya. Pada individu yang mempunyai external locus of control akan memandang dunia sebagai sesuatu yang tidak dapat diramalkan, demikian juga dalam mencapai tujuan sehingga perilaku individu tidak akan mempunyai peran di dalamnya. Dengan demikian dapat disimpulkan bahwa individu yang mempunyai external locus of control diidentifikasikan lebih banyak menyandarkan harapannya untuk bergantung pada orang lain dan lebih banyak mencari dan memilih situasi yang menguntungkan. Sementara itu individu yang mempunyai internal locus of control diidentifikasikan lebih banyak menyandarkan harapannya pada diri sendiri dan diidentifikasikan juga lebih menyenangi keahlian-keahlian dibanding hanya situasi yang menguntungkan.

Locus Of Control adalah sebagai tingkat dimana individu yakin bahwa mereka adalah penentu nasib mereka sendiri. Internal adalah individu yang yakin bahwa mereka merupakan pemegang kendali atas apa-apa pun yang terjadi pada diri mereka, sedangkan eksternal adalah individu yang yakin bahwa apapun yang terjadi pada diri mereka dikendalikan oleh kekuatan luar seperti keberuntungan dan kesempatan.

Rotter (1975) menyatakan bahwa internal dan eksternal mewakili dua ujung kontinum, bukan bukan secara terpisah. Internal cenderung menyatakan bahwa sebuah peristiwa berada pada control mereka sendiri, sementara eksternal lebih cenderung menyalahkan factor luar yang mempengaruhi suatu kejadian yang menimpa mereka.

H3: Locus of control berpengaruh terhadap kinerja manajerial

\section{METODE PENELITIAN}

Pengumpulan data pada penelitian ini dilakukan dengan data primer yaitu penelitian lapangan melalui pembagian kuesioner kepada subjek penelitian yang dituju. Adapun kriteria responden yang digunakan adalah para pimpinan, pejabat pengelola keuangan, dan Satuan Pemeriksa Intern (SPI) di lingkungan UIN Syarif Hidayatullah Jakarta. Ukuran sampel ditetapkan dengan cara Non Statistical Sampling, di mana besarnya sampel tanpa menggunakan rumus perhitungan penentuan besarnya sampel. Teknik penarikan sampel dalam penelitian ini adalah dengan menggunakan metode Purposive Sampling yang termasuk dalam non-probability sampling yaitu tipe pemilihan sampel secara tidak acak yang informasinya diperoleh dengan menggunakan pertimbangan tertentu disesuaikan dengan tujuan dan masalah penelitian (Indriantoro dan Supomo, 2002). Instrumen penelitian berupa kuesioner yang berhubungan dengan indikator yaitu 
kuesioner Kinerja manajerial, kuesioner kejelasan sasaran anggaran, kuesioner struktur desentralisasi dan kuesioner locus of control yang menghasilkan data interval.

\section{Definisi Operasional Variabel}

Operasional dari masing-masing variabel yang ada di dalam penelitian ini dijelaskan dalam tabel 1 di bawah ini:

Tabel 1. Operasional Variabel Penelitian

\begin{tabular}{|c|c|c|}
\hline Variabel & Indikator & Skala \\
\hline $\begin{array}{l}\text { Kejelasan sasaran } \\
\text { anggaran (X1) } \\
\text { (Bangun, 2009) }\end{array}$ & $\begin{array}{l}\text { 1. Ada kejelasan sasaran anggaran pada } \\
\text { satuan kerja ini. } \\
\text { 2. Ada spesifikasi sasaran anggaran pada } \\
\text { satuan kerja ini. } \\
\text { 3. Saya dapat mengetahui tingkat } \\
\text { kepentingan sasaran anggaran pada setiap } \\
\text { program. } \\
\text { 4. Saya dapat mengetahui secara jelas } \\
\text { outcome yang harus dicapai pada setiap } \\
\text { program dan kegiatan. } \\
\text { 5. Anggaran yang dibuat telah } \\
\text { mempertimbangkan skala prioritas. } \\
\text { 6. Indikator kinerja untuk setiap kegiatan } \\
\text { yang tercantum dalam anggaran telah } \\
\text { terdefinisi dengan jelas dan terukur. }\end{array}$ & $\begin{array}{l}\text { Ordinal } \\
\text { Ordinal } \\
\text { Ordinal } \\
\text { Ordinal } \\
\text { Ordinal } \\
\text { Ordinal }\end{array}$ \\
\hline $\begin{array}{l}\text { Struktur } \\
\text { Desentralisasi } \\
\left(\mathrm{X}_{2}\right) \\
(\text { Bangun, 2009) }\end{array}$ & $\begin{array}{l}\text { 1. Saya mempunyai wewenang untuk } \\
\text { menentukan jumlah anggaran untuk } \\
\text { satuan kerja saya. } \\
\text { 2. Saya mempunyai wewenang untuk } \\
\text { menentukan program dan kegiatan di } \\
\text { satuan kerja saya } \\
\text { 3. Saya mempunyai wewenang untuk } \\
\text { menentukan pegawai yang terlibat dalam } \\
\text { program dan kegiatan. } \\
\text { 4. Saya mempunyai wewenang untuk } \\
\text { menentukan prioritas kegiatan yang akan } \\
\text { dilaksanakan. } \\
\text { 5. Saya mempunyai wewenang untuk } \\
\text { menentukan penambahan pegawai di } \\
\text { satuan kerja saya. } \\
\text { 6. Saya mempunyai wewenang untuk } \\
\text { menentukan pemutasian pegawai. }\end{array}$ & $\begin{array}{l}\text { Ordinal } \\
\text { Ordinal } \\
\text { Ordinal } \\
\text { Ordinal } \\
\text { Ordinal } \\
\text { Ordinal }\end{array}$ \\
\hline $\begin{array}{l}\text { Locus Of Control } \\
\left(\mathbf{X}_{3}\right) \\
\text { Baron dan Byren } \\
(1994) \text { dalam Astuti } \\
(2007)\end{array}$ & $\begin{array}{l}\text { 1. Saya memperoleh kehormatan sebagai } \\
\text { sesuatu } \\
\text { 2. Keberhasilan yang terjadi adalah hasil } \\
\text { perbuatan saya sendiri } \\
\text { 3. Apa yang saya peroleh tidak ada } \\
\text { kaitannya } \\
\text { 4. Memilih seseorang untuk menempati } \\
\text { sesuatu jabatan ditentukan oleh }\end{array}$ & $\begin{array}{l}\text { Ordinal } \\
\text { Ordinal } \\
\text { Ordinal } \\
\text { Ordinal }\end{array}$ \\
\hline
\end{tabular}




\begin{tabular}{|c|c|c|}
\hline Variabel & Indikator & Skala \\
\hline & $\begin{array}{l}\text { kemampuannya } \\
\text { 5. Tidak berhasil yang terjadi akibat } \\
\text { perbuatan saya sendiri } \\
\text { 6. Saya membuat perencanan dan mampu } \\
\text { mewujudkannya } \\
\text { 7. Apabila terjadi kesalahan saya bersedia } \\
\text { mengakuinya } \\
\text { 8. Pemimpin yang baik mengharapkan } \\
\text { pegawai memutuskan sendiri apa yang } \\
\text { sebaiknya mereka lakukan } \\
\text { 9. Hasil Kerja yang berharga sering saya } \\
\text { abaikan } \\
\text { 10. Saya merasa memiliki tidak cukup kendali } \\
\text { untuk mengarah tujuan hidup } \\
\text { 11. Saya memutuskan untuk sesuatu dengan } \\
\text { melemparkan mata uang } \\
\text { 12. Yang menjadi pimpinan tergantung } \\
\text { kepada keberuntungan yang melekat } \\
\text { pada seseorang } \\
\text { 13. Kejadian buruk yang terjadi akibat } \\
\text { ketidakmujuran } \\
\text { 14. Membuat perencanaan yang terlalu jauh } \\
\text { ke depan adalah pekerjaan sia-sia } \\
\text { 15. Hal yang terbaik adalah menutupi } \\
\text { kesalahan orang lain } \\
\text { 16. Pemimpin yang baik adalah memperjelas } \\
\text { pekerjaan karyawannya }\end{array}$ & $\begin{array}{l}\text { Ordinal } \\
\text { Ordinal } \\
\text { Ordinal } \\
\text { Ordinal } \\
\text { Ordinal } \\
\text { Ordinal } \\
\text { Ordinal } \\
\text { Ordinal } \\
\text { Ordinal } \\
\text { Ordinal } \\
\text { Ordinal } \\
\text { Ordinal }\end{array}$ \\
\hline $\begin{array}{l}\text { Kinerja } \\
\text { manajerial } \\
\text { Satuan Kerja (Y) } \\
\text { (Bangun, 2009) }\end{array}$ & $\begin{array}{l}\text { 1. Anggaran Satuan Kerja dapat disusun } \\
\text { sesuai dengan kalender anggaran. } \\
\text { 2. Program dan kegiatan dapat dilaksanakan } \\
\text { sesuai dengan waktu yang ditentukan. } \\
\text { 3. Proses penatausahaan keuangan Satuan } \\
\text { Kerja telah berjalan sesuai dengan } \\
\text { seharusnya. } \\
\text { 4. Laporan pertanggungjawaban SPJ dapat } \\
\text { diserahkan Sesuai dengan aturan. } \\
\text { 5. Laporan keuangan Satuan Kerja dapat } \\
\text { diselesaikan sesuai dengan waktu yang } \\
\text { ditentukan. } \\
\text { 6. Saya dapat mengarahkan, memimpin dan } \\
\text { mengembangkan anak buah. }\end{array}$ & $\begin{array}{l}\text { Ordinal } \\
\text { Ordinal } \\
\text { Ordinal } \\
\text { Ordinal } \\
\text { Ordinal } \\
\text { Ordinal }\end{array}$ \\
\hline
\end{tabular}

\section{Teknik Analisa Data}

Teknik analisis data pada penelitian ini adalah dengan menggunakan model regresi berganda. Teknik analisis data yang digunakan adalah dengan uji kualitas data yaitu, uji validitas dan uji reliabilitas serta uji asumsi klasik yaitu uji normalitas data, uji multikolinieritas, dan uji heteroskedastisitas serta uji statistik t (uji signifikansi parameter individual). Pengolahan data menggunakan software SPSS Versi 22. 
Model yang digunakan dalam penelitian ini menggunakan model regresi linier berganda dijabarkan di bawah ini:

$\mathrm{Y}=\mathrm{a}+\mathrm{bX} 1+\mathrm{bX}_{2}+\mathrm{bX}_{3}+e$

Dalam hal ini:

$\mathrm{Y}=$ Kinerja Manajerial (variabel terikat)

$\mathrm{a}=$ Konstanta, harga $\mathrm{Y}$ bila $\mathrm{X}=\mathrm{o}$

$\mathrm{b}=$ Koefisiensi regresi yang menunjukkan angka peningkatan ataupun penurunan variabel terikat $(\mathrm{Y})$ yang didasarkan pada variabel bebas $(\mathrm{X})$. Bila b $(+)$ maka naik dan bila b (-) maka terjadi penurunan.

$\mathrm{X}_{\mathbf{1}}=$ Kejelasan sasaran anggaran (Variabel bebas)

$\mathrm{X}_{2}=$ Struktur Desentralisasi (Variabel bebas)

$\mathrm{X}_{3}=$ Locus of control (variabel bebas)

$e=$ Standar error

\section{HASIL DAN PEMBAHASAN}

Data yang diperlukan untuk mengukur pengaruh kejelasan sasaran anggaran, struktur desentralisasi dan locus of control terhadap kinerja manajerial dengan menyebarkan kuesioner kepada pada pimpinan dan pejabat pengelolaan Keuangan UIN Syarif Hidayatullah Jakarta. Jumlah kuesioner yang disebarkan sebanyak 77 kuesioner yang dikirim ke 11 fakultas, dan rektorat. Dari jumlah tersebut, tingkat pengembaliannya hanya $84 \%$ atau sebayak 65 kuesioner, sedangkan sisanya $16 \%$ atau sebanyak 12 kuesioner tidak kembali di karenakan kesibukan para pimpinan. Dengan demikian, jumlah kuesioner yang dapat digunakan sebagai data penelitian untuk dianalisis lebih lanjut adalah sebanyak 65 kuesioner.

Dari data yang diolah responden yang berjenis kelamin perempuan lebih mendominasi yaitu sebanyak 41 orang (63\%), dan laki-laki sebanyak 24 orang (37\%). Sedangkan jenjang pendidikan, S1 lebih mendominasi yaitu 33 orang (51\%), S2 sebanyak 26 orang $(40 \%), S_{3}$ sebanyak 4 orang $(6 \%)$, dan $D_{3}$ sebanyak 2 orang (3\%). Untuk jabatan satuan pemeriksa intern lebih mendominasi yaitu sebanyak 20 orang (30\%), Kasubbag sebanyak 16 orang (25\%), Kepala Bagian sebanyak 9 orang (14\%), kepala Jurusan 7 orang (11\%), Wakil dekan bidang administrasi umum 7 orang (11\%), dan Bedahara 6 (9\%). Responden yang menduduki golongan III lebih mendominasi yaitu sebanyak 53 orang $(82 \%)$, dan golongan IV sebanyak 12 orang $(18 \%)$.

\section{Hasil Pengujian Hipotesis}

Hasil pengujian hipotesis dapat dilihat pada tabel berikut ini: 


\begin{tabular}{||r|r|r|r|r|l|}
\hline \multirow{2}{*}{ Model } & \multicolumn{2}{|l|}{$\begin{array}{l}\text { Unstandardized } \\
\text { oefficients }\end{array}$} & $\begin{array}{l}\text { Standardized } \\
\text { Coefficients }\end{array}$ & \multirow{2}{*}{$t$} & \multirow{2}{*}{ Sig. } \\
\cline { 2 - 5 } & B & $\begin{array}{l}\text { Std. } \\
\text { Error }\end{array}$ & Beta & & \\
\hline (Constant) & 9,422 & 3,508 & & 2,686 &, 009 \\
\hline Kejelasan Sasaran Anggaran &, 415 & 105 &, 428 & 3,939 &, 000 \\
\hline Struktur Desentralisasi &, 167 & 058 &, 311 & 2,881 &, 005 \\
\hline Locus Of Control &, 034 & 046 &, 081 &, 741 &, 461 \\
\hline
\end{tabular}

Dependent Variable: Kinerja Manajerial

Berdasarkan hasil pengujian hipotesis pertama menunjukkan bahwa secara parsial kejelasan sasaran anggaran berpengaruh secara signifikan terhadap Kinerja Maajerial. Hasil Penelitian ini juga sesuai dengan penelitian Suhartono dan Halim (2005) dalam bangun (2009) yang menyimpulkan kejelasan sasaran anggaran berpengaruh positif signifikan terhadap kinerja manajerial Pemda. Hasil penelitian sejalan dengan apa yang dikemukakan oleh Kenis (1979) dalam bangun (2009), bahwa kejelasan sasaran anggaran merupakan sejauh mana tujuan anggaran ditetapkan secara jelas dan spesifik dengan tujuan agar anggaran tersebut dapat dimengerti oleh orang yang bertanggung jawab atas pencapaian sasaran tersebut.

Oleh sebab itu sasaran anggaran daerah harus dinyatakan secara jelas, spesifik dapat dimengerti oleh mereka yang bertanggungjawab untuk melaksanakannya. Kenis (1979) dalam bangun (2009) menyatakan bahwa penetapan tujuan spesifik akan lebih produktif dari pada tidak menetapkan tujuan spesifik. Hal ini akan mendorong karyawan untuk melakukan yang terbaik bagi pencapaian tujuan yang dikehendaki sehingga dapat berimplikasi pada peningkatan kinerja.

Hasil penelitian ini juga berbeda dengan hasil penelitian yang dilakukan Syafrial (2009), menyimpulkan bahwa kejelasan sasaran anggran berpengaruh secara signifikan terhadap kinerja managerial SKPD. Perbedaan hasil penelitian ini mungkin disebabkan ada perbedaan karakter dari individu dalam penyusunan anggaran satuan kerja perangkat daerah di Kabupaten Deli Serdang dengan di Kabupaten Saralangon.

Sistem pengukuran kinerja yang dapat mengindikasikan orientasi pemenuhan kepuasan/kebutuhan masyarakat adalah penetapan indikator dan target kinerja yang jelas dan terukur. Penetapan indikator dan target kinerja merupakan tahap penting yang harus dilakukan secara hati-hati. Penetapan indikator dan target kinerja penting untuk menentukan keberhasilan satuan kerja perangkat daerah dalam melaksanakan program dan kegiatan. Penetapan kinerja diharapkan tidak menimbulkan kesenjangan penilaian antara masyarakat dan pemerintah daerah.

Kenis (1979) dalam Bangun (2009) mengatakan kejelasan sasaran anggaran disengaja untuk mengatur perilaku karyawan. Ketidakjelasan sasarana anggaran akan menyebabkan pelaksana anggaran menjadi bingung, tidak tenang dan tidak puas dalam bekerja. Hal ini menyebabkan pelaksanaan anggaran tidak termotivasi untuk mencapai kinerja yang diharapkan.

Berdasarkan hasil pengujian hipotesis kedua menunjukkan bahwa struktur desentralisasi mempunyai pengaruh yang signifikan terhadap kinerja manajerial. Hal ini sejalan dengan penelitian Syafruddin (2005) dan Bangun (2009) serta pendapat para akademisi maupun praktisi di bidang bisnis termasuk akuntasi yang menyatakan bahwa 
tingkat atau intensitas partisipasi anggaran dan derajat struktur organisasi yang terdesentralisasi akan meningkatkan atau menurunkan kinerja orang yang terlibat dalam partisipasi dan struktur tersebut.

Struktur Organisasi desentralisasi secara umum ditujukan dengan pengambilan keputusan yang terjadi dalam organisasi. Dalam struktur sentralisasi yang tinggi, sebagian keputusan diambil pada tingkat hirarki organisasi yang tertinggi, dan apabila sebagian otorisasi didelegasikan pada level yang rendah dalam organisasi, maka organisasi tersebut lebih desentralisasi. Desentralisasi akan menunjukkan tingkat otonomi yang didelegasikan pada manajerial sehingga manajerial mempunyai tanggung jawab yang lebih besar terhadap perencanaan dan pengendalian aktivitas operasi serta membutuhkan informasi yang lebih banyak. Jadi organisasi yang strukturnya lebih terdesentralisasi

Sedangkan hasil pengujian hipotesis ketiga pada penelitian ini menyatakan bahwa locus of control tidak berpengaruh kinerja manajerial, oleh karenanya penelitian ini Sejalan dengan hasil yang dicapai oleh Ngatemin (2008) dimana dalam penelitian tersebut diperoleh hasil bahwa locus of control tidak dapat menjelaskan terhadap kinerja aparat.

Penelitian ini yang dilakukan terhadap para pejabat struktural Badan Pengembangan Sumber Daya Kebudayaan dan Pariwisata menyatakan bahwa locus of control yang diinteraksikan terhadap kinerja manajerial karena hasilnya tidak signifikan, dimana responden tidak merespon locus of control sebagai variabel yang menentukan dengan kinerja manajerial, dengan demikian maka variabel locus of control tidak perlu dijadikan sebagai pertimbangan dalam menentukan kebutuhan informasi seorang manajer dalam upaya meningkatkan kinerja manajerial.

\section{SIMPULAN}

Berdasarkan data yang diperoleh dan hasil pengujian yang telah dilakukan dengan menggunakan model regresi berganda, maka dapat disimpulkan bahwa kejelasan sasaran anggaran berpengaruh secara signifikan terhadap kinerja manajerial. Struktur desentralisasi berpengaruh secara signifikan terhadap kinerja manajerial. Sedangkan locus of control tidak berpengaruh secara signifikan terhadap kinerja manajerial.

\section{PUSTAKA ACUAN}

Astuti, ED. (2007). Pengaruh Ketidakpastian Lingkungan Terhadap Karekteristik Informasi Sistem Akuntansi Manajemen dengan Moderasi Locus of Control Pada Perusahaan Manufaktur di Daerah Istimewa Yogyakarta dan Jawa Tengah, Tesis, Universitas Islam Indonesia Yogyakarta.

AZIS, NOOR. (2011). Analisis pengaruh partisipasi penyusunan anggaran, kejelasan anggaran dan umpan balik terhadap peningkatan kinerja manajerial melalui kepuasan kerja dan ketidakpastian lingkungan sebagai variabel moderating. Jurnal analisis manajemen. vol 5, no 1

Badriyah, Nurul, Sari Ria Nelly, dan Savitri Enni (2013). Pengaruh Partisipasi Penyusunan Anggaran, Kejelasan Sasaran Anggaran, Kesulitan Sasaran Anggaran, Evaluasi Anggaran Dan Umpan Balik Anggaran Terhadap Kinerja Manajerial. Universitas Riau

Bangun. Andarias. (2009). Pengaruh partisipasi dalam penyusunan anggaran, Kejelasan sasaran anggaran dan struktur Desentralisasi terhadap kinerja manajerial SKPD dengan pengawasan internal sebagai Variabel pemoderasi (studi kasus pada Pemerintah kabupaten deli serdang. Medan: Sekolah Pasca Sarjana Universitas Sumatera Utara.

Bastian, Indra. (2006). Akuntansi Sektor Publik: Suatu Pengantar. Jakarta: Erlangga. 
Dharma, Emile Setia. (2004). Pengaruh Kejelasan Sasaran Anggaran dan Sistem Pengendalian Akuntansi Terhadap Kinerja Manajerial dengan Komitmen Organisasi Sebagai Variabel Pemoderisasi pada Pemerintah Daerah, Studi Empiris pada Kabupaten dan Kota Se-Propinsi Daerah Istimewa Yogyakarta, Bali: Simposium Nasional Akuntansi VII.

Ghozali, Imam. (2005). Aplikasi Multivariate dengan Program SPSS. Semarang: Universitas Diponegoro

Halim, Abdul, (2007). Akuntansi Sektor Publik, Akuntansi keuangan Daerah, Edisi 3, Jakarta: Salemba Empat.

Mardiasmo. (2001). Desentralisasi Sistem dan Desentralisasi Fiskal. Yogyakarta: Fakultas Ekonomi Universitas Gadjah Mada. (2005). Akuntansi Sektor Publik. Yogyakarta: Andi.Ofset

Nafarin, M. (2004). Penganggaran Perusahaan, Edisi Revisi, Salemba Empat, Jakarta.

Nawawi, Hadari. (2002). Manajemen Sumber Daya Manusia Untuk Bisnis Yang Kompetitif. Yogyakarta: Gadjah Mada University Press.

Nordiawan, Deddi (2006). Akuntansi Sektor Publik. Jakarta: Salemba Empat.

Prawirosentono.S. (1999). Manajemen Sumber Daya Manausia, Kebijakan Kinerja Karyawan. Yogyakarta: BPFE.

Renyowijoyo, Muindro.(2010). Akuntansi Sektor Publik Organisasi Non Laba. Jakarta: STIE TRISAKTI.

Saerang, David dan Wokas Heince (2011). Pengaruh Kejelasan Sasaran Anggaran Terhadap Kinerja Pemerintah Pada Pemerintah Kota Tomohon. Manado: Jurnal riset Akuntansi dan AuditingMagister Akuntansi Fakultas ekonomi Unsrat, Volume 2, Nomor 1

Sagara, Yusar. (2011). Analisa Pengelolaan Keuangan Sebelum dan Setelah Ditetapkan Sebagai Satuan Kerja (satker) BLU Terhadap Peningkatan Kinerja Keuangan dan Kinerja Administrasi Studi Kasus UIN Syarif Hidayatullah Jakarta. Jakarta: Program Magister Akuntansi Universitas Trisakti.

Stoner, James A.F. (1986). Manajemen. Jilid II.Edisi Kedua Terjemahan. Jakarta: Erlangga

Syafrial.(2009). Pengaruh Ketepatan Skedul Penyusunan Anggaran, Kejelasan Sasaran Anggaran Dan Partisipasi Penyusunan Anggaran Terhadap Kinerja Manajerial Skpd Pada Pemerintah Kabupaten Sarolangun. Medan: Sekolah Pasca Sarjana Universitas Sumatera Utara.

Suhartono, Erhmann dan Halim, Abdul. (2006). Pengaruh Kejelasan Sasaran Anggaran Terhadap Senjangan Anggaran Instansi Pemerintah Daerah Dengan Komitmen Organisasi Sebagai Pemoderasi. Padang: Simposium Nasional Akuntansi IX.

Supratiningrum dan Zulaikha, (2003). Pengaruh Total Quality Management terhadap Kinerja Manajerial dengan Sistem Pengukuran Kinerja dan Sistem Penghargaan (Reward) sebagai variabel Moderating (Studi empiris pada Hotel di Indonesia), Simposium Nasional Akuntansi VI, Oktober, Hal. 775-789.

Yuwono, Sony. (2005). Penganggaran Sektor Publik, Bayumedia Publishing, Jatim 